\title{
Dereleme/Review \\ Genetiği Değiştirilmiş Bitkilerin Biyolojik Çeşitliliğe Potansiyel Etkileri
}

\author{
Yunus Emre ARVAS ${ }^{1 *}$, Yilmaz KAYA ${ }^{2}$ \\ ${ }^{1}$ Yıldız Teknik Üniversitesi, Fen Bilimleri Enstitüsü, Moleküler Biyoloji ve Genetik Anabilim Dalı, İstanbul- Türkiye \\ ${ }^{2}$ Ondokuz Mayıs Üniversitesi Ziraat Fakültesi Tarımsal Biyoteknoloji Anabilim Dalı, Samsun- Türkiye \\ *e-posta: yunusearvas@gmail.com
}

\begin{abstract}
Öz: Son yıllarda genetiği değiştirilmiş organizmalar (GDO) ile ilgili tartışmalar yaşanırken, bu organizmaların üretim miktarları her geçen yıl artmaktadır. Günümüzde rekombinant DNA metotlarının kullanımı ile elde edilen ürünlerin ülkemizde kullanımı yasak olmasına rağmen hayvan yemi olarak ülkemize yasal olarak girmektedir. Global olarak, genetiği değiştirilmiş ürünlerin çevreye salınımlarından sonra kamusal endişeler artmıştır ve bu yüzden ülkeler bazında yasal düzenlemeler yapılmıştır. Biyoçeşitlilik, en temel anlamıyla canlı organizmaların çeşitliliği anlamındadır. Tarımsal biyolojik çeşitlilik ise gıda ve tarımla ilgili biyolojik çeşitliliğin tüm bileşenlerini içermektedir. Ekin türleri, çiftlik hayvanları, balık türleri genetik kaynakları ve tarla, orman, otlak ve su ekosistemleri dâhilinde evcilleştirilmemiş tüm kaynaklar tarımsal biyolojik çeşitliliğin kapsamına girmektedir. Son elli yılda dünya nüfusunun hızla artması ile birlikte genetik çeşitlilik azalmıştır. Bununla birlikte, genetiği değiştirilmiş organizmaların çevreye salınımı ile biyoçeşitliliğe etkisi kamusal kaygı olarak ortaya çıkmaktadır. GDO'ların çevreye salınımları halinde çoğunlukla kontrolsüz tozlaşma, gen kaçışı ve yabani hibritleşme gibi ortaya çıkabilecek riskleri vardır. Bu çalışmada genetiği değiş̧irilmiş bitkilerin biyoçeşitliliğe etkileri, riskleri ve olası faydaları değerlendirilmiş̧ir.
\end{abstract}

Anahtar kelimeler: Biyoçeşitlilik, Genetiği değiştirilmiş bitki, GDO

\section{Potential Impact of Genetically Modified Plants on Biodiversity}

\begin{abstract}
Currently, the introduction of genetically modified organisms (GMOs) has raised some concerns and the planting areas of these organisms continue to expand every year. In recent years, it is forbidden to cultivate food and feeds produced with genetic engineering technology in Turkey. Transgenic products that have come to Turkey through imports have taken their place in the markets through various inspections and their sales continue. Biodiversity means the diversity of life. Agricultural biological diversity includes all components of biological diversity related to food and agriculture. Genetic resources such as crop species, farm animals, fish species, and all untamed animals, forest, grassland and aquatic ecosystems within the scope of agricultural biological diversity. However, with the increasing living organism population, the rate of consumption of natural resources is also increasing. Thereby reducing the genetic diversity for biodiversity. Genetically modified organisms can have some negative consequences There are negative effects that plants may produce in the environment such as uncontrolled pollution, gene leaks and wild hybridization. In this review, the impacts, risks and benefits of genetically modified plants on biodiversity have been evaluated.
\end{abstract}

Keywords: Biodiversity, Genetically modified plant, GMO

\section{Giriş}

İnsanlar, tarih boyunca doğal seleksiyon etkisi ile gelişen canlı türlerini ihtiyaçları dâhilinde kullanmışlardır. Tarım ile uğraşan insanlar Roma ve eski mısır ülkelerinde olduğu gibi kullandıkları en iyi kaliteye sahip tohumları saklayarak sonraki senelerde ekmişlerdir. Klasik ıslah yöntemlerinin kullanılmaya başlanması ile de yetiştiriciliği yapılan bazı bitkilerin üstün özellikli olmaları sağlanmıştır. Bunun sonucunda da ürün artışı sağlanmıştır. Bununla beraber; keçi, inek gibi bazı hayvanlardan da evcilleştirilerek bu hayvanlardan daha fazla faydalanılmıştır (Atsan ve Kaya 2008).

Dünya nüfusunun sürekli artmasından dolayı ortaya çıkan beslenme sorununun giderilmesi amacıyla birim alandan alınan verimin artırılması; ekilebilir alan artırılmasından daha çok önem kazanmış ve çalışmalara bu yönde ağırlık verilmiştir. Yeşil devrim olarak adlandırılan (1965-1985) dönemde, klasik sslah yöntemleri ile birlikte gübreler, sentetik gübreler, hormonlar, herbisitler, insektisitler, fungusitler ve son teknolojik makinelerin kullanılmasıyla, elde edilen bitkisel ürünlerin kalite ve veriminde kayda değer büyük başarılar elde edilmiştir. Fakat ilerleyen yıllarda herbisitler gibi pestisitlerin toprakta birikmeye başlaması, çevre ve insan sağlığına kalıcı zarar vermeleri ve geleneksel 1slah yöntemleriyle elde edilen ürünlerin çok zaman alması bunun beraberinde yoğun bir iş gücü masrafını getirmesi, bununla beraber melezleme yapılabilecek türlerin az olması gibi dezavantajlardan dolayı yeşil devrim yetersiz 
kalmıştır. Klasik ıslah yöntemleri ihtiyaçları karşılayamaz hale gelmiş ve giderek artan ihtiyaçlardan dolayı yeni arayışlara başlanılmış ve bunun neticesinde genetiği değiştirilmiş organizmalar hayatımıza girmeye başlamıştır (Kaya 2015).

Transgenik bitkiler elde edilmesi için yapılan çalışmalar, 1980'li yıllarda ülkeler arası bir konsorsiyum tarafından Agrobacterium tumafaciens bakterisinin aracılığı ile gen aktarımı teknolojisinin kullanılmaya başlanması ile adeta bir devrim yaşanmıştır ve bunun neticesinde uzun raf ömrüne sahip domates de dahil olmak üzere çok sayıda GD bitki geliştirilmiştir (Bawa ve Anilakumar 2013). Genetiği değiştirilmiş organizmalar ile ilgili ilk çalışmalar ABD’de başlanmıştır ve ilk genetiği değiştirilmiş organizma olan Escherichia coli 1973 yılında laboratuvarda elde edilmiştir (National Human Genome Research Institute 2015). 1983 yılında dünyada ilk defa genetiği değiştirilmiş tütün bitkisi elde edilmiştir (Herrera-Estrella ve ark. 1983; Kenward ve ark. 1993). Açık alanda ise ilk defa "Bacillus thuringensis" bakterisinin genini barındıran genetiği değiştirilmiş mısır bitkisinin ekimi ABD’ de yapılmıştır (Yılmaz 2012). Ticareti yapılan genetiği değiştirilmiş ilk bitki ise 1994 yılında ABD pazarlarında satılmaya başlayan ve "Flavr Savr" adı verilen, uzun raf ömrüne sahip domates olmuştur. İlerleyen yıllarda ise genetiği değiştirilmiş bitki çeşit sayısı artarak devam etmiştir (Şen ve Altınkaynak 2014). Rekombinant DNA teknolojisi kullanılarak transgenik ürün elde edilmesinin amacı birim alandan alınan verimi arttırmak ve çevresel stres faktörlerine dayanıklı ürünler yetiştirmektir. Nitekim dünya genelinde 1996 yılında 1,7 milyon hektar GDO’lu ürün ekimi yapılmışken, 2017 yılında bu rakam 189,8 milyon hektara ulaşmıştır (Şekil 1) (ISAAA 2017). Gelişen dünyada her geçen gün yeni bir teknolojinin hayatımıza girmesinden dolayı, GDO çalışmaları ve ürünleri hem çok büyük bir talep ve kabul görmüş hem de tepki ile karşılanmıştır (Arun ve ark. 2015).

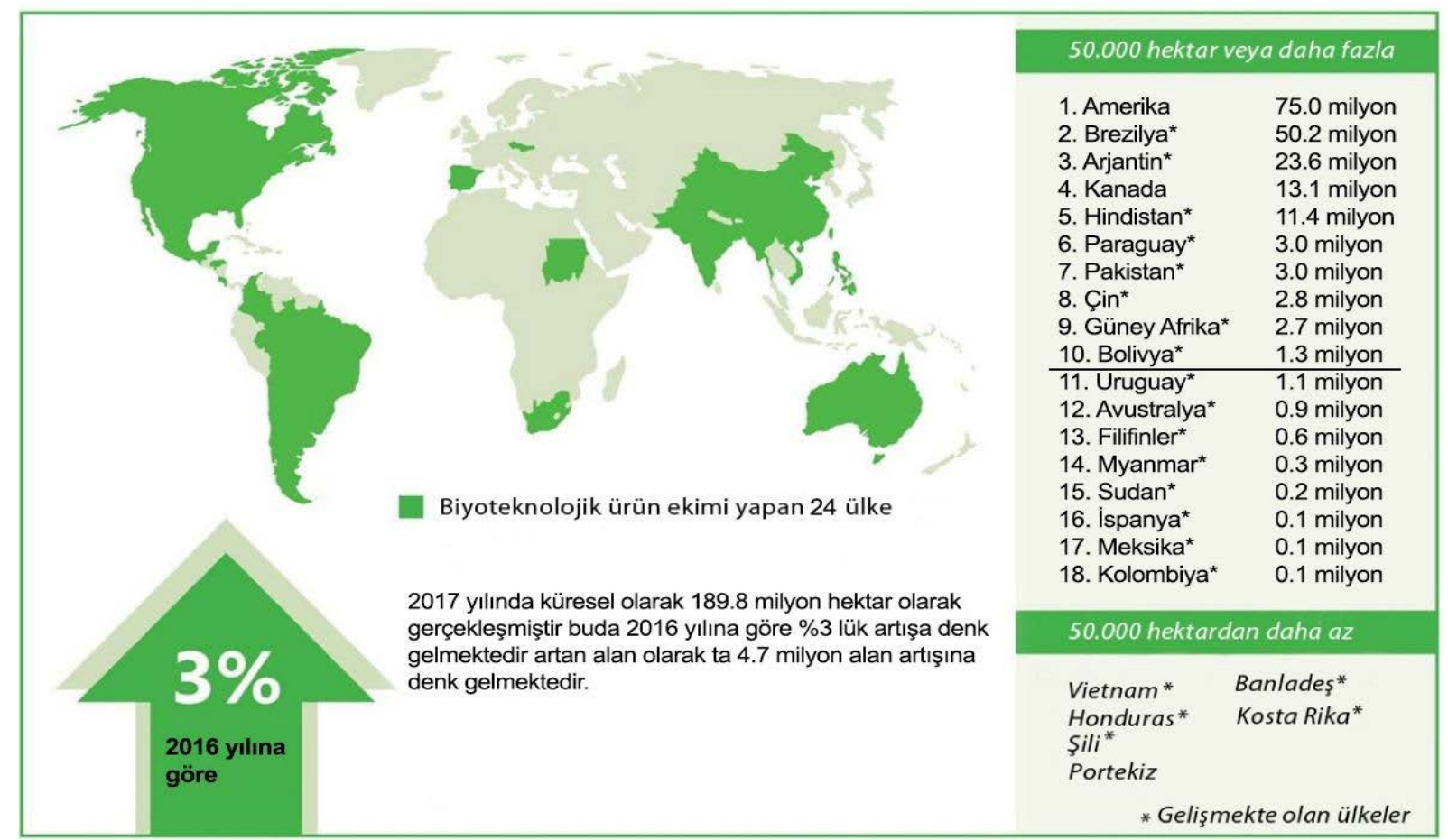

Şekil 1. Dünyada en fazla GD ürün üreten ülkelerin sıralaması (ISAAA 2017).

\section{Genetiği Değiştirilmiş Organizmalar}

Rekombinant DNA teknolojisi; canlı bir organizmadan herhangi bir yöntemle elde edilen bir genin uygun bir konak hücreye aktarılarak çoğaltılmasını ve/veya ifade edilmesini amaçlayan çalışmalar bütününe verilen addır (Yorulmaz ve Ay 2006). Rekombinant DNA basitçe ifade etmek gerekirse, iki farklı türden DNA'nın birleştirilmesiyle ortaya çıkan DNA molekülü olarak tanımlanmaktadır. Rekombinasyon; genotipleri farklı bireyler arasında eşleşmeler gerçekleştiğinde, anne ve babaya ait kalıtsal özelliklerin döllerde değişik gruplanmalar oluşturacak şekilde bir araya gelmesini sağlayan olaylar dizisidir. Bu olaylar zinciri, dizileri birbirinden farklı nükleotidlere sahip iki DNA molekülünün homoloji gösteren bölgeleri arasındaki parça alış-verişi sonucunda moleküler düzeyde meydana gelen yeni gruplamalardır (Firidin 2010; Soydemir ve Aksoy 2017).

Rekombinasyon'un temelleri, ilk kez 1928 yılında İngiliz bilim insanı Frederick Griffith tarafından atılmıştır. O dönemde Londra' da zatürre salgını oluşmasına neden olan bakteriler üzerinde çalışmış, genetik materyalin hücreler arasında iletildiğini ve yeni bir genetik bilgiye dönüştürüldüğünü ispat etmiş ve buna "genetik transformasyon" adını vermiştir (Pray 2008; Gostin ve ark. 2014; Krebs ve ark. 2014). 1973 yılında Stanley Cohen ve Annie Chang tarafından 
tanımlanan ve rekombintant DNA teknolojisinin temelini oluşturan ilk in vitro plasmid geliştirilmiştir (Kiermer 2007; Gostin ve ark. 2014). O zamandan beri rekombinant DNA teknolojisi gün geçtikçe gelişimini devam ettirmiştir. Rekombinant DNA teknolojisi, hedefteki bir genin çok miktarda üretilmesini veya hedefteki geni ifade etmeyen bir hücrenin, o geni ifade edebilmesini amaçlamaktadır (Soydemir ve Aksoy 2017). Rekombinant DNA, vektör plasmidi ve hedeflenen geni içeren DNA parçası olmak üzere iki ana parçadan oluşmaktadır (Lodish ve ark. 2007). Rekombinant DNA teknolojileri kullanılarak bir organizmaya, başka bir organizmadan; yeni bir gen transfer edilmesi ile oluşturulan canlıya Genetiği Değiştirilmiş Organizma (GDO) denir. GDO'lu canlılara aktarılan bu gen, kendi cinslerinden bir gen taşıyabileceği gibi başka cins ve türlerden de gen barındırabilir hatta sentetik olarak üretilen genlerden de alınan gen olabilir. Örneğin tütün bitkisine rekombinant DNA teknolojileri kullanılarak Rizobium sp'den gen aktarılmasıyla dalapon herbisitine dayanıklı genetiği değiştirilmiş tütün elde edilmiştir (Kaya ve ark. 2013).

$\mathrm{Bu}$ ve benzeri biyoteknolojik çalışmalar neticesinde bitkiler biyotik ve/veya abiyotik streslere karşı dayanıklı hale gelebilmektedirler. Örneğin, dalapon herbisiti stresine maruz kalan tarım alanlarında tarımsal önemi olan bitkilerin verimi düşmekte ve toprağın ekonomik değeri azalmaktadır. Fakat modern biyoteknoloji metotlarıyla bakteriden alınan dehalogenase genlerinin bitkiye transferi sayesinde dalapon herbisitine dirençli bitki geliştirmek mümkün olmuştur. Ayrıca bu genin bitkide anlatımı sayesinde topraktan dalapon herbisiti bünye içine alarak toprağı temizlemektedir. Bunun yanı sıra, bu gen sayesinde bünye içindeki dalapon herbisiti pirüvik asite çevrilerek herbisit kalıntısı da ortadan kaybolmaktadır (Kaya ve ark. 2013). Kuraklık, ağır metal ve hava sıcaklığının ekstrem olduğu bölgelerde yüksek tolerans sağlaması beklenen genlerin yeni biyoteknoloji metotlarıyla bitkilere aktarılması ile bu bitkilerin bu alanlarda yetiştirilmeleri mümkün olmaktadır (Hoffmann 1997). Funguslar, zararlılar, nematotlar ve virüsler gibi biyotik streslere karşı bitkiler geliştirilebilmektedir (Melchers ve Stuiver 2000). Bu ve benzeri sebeplerden dolayı genetiği değiştirilmiş organizmalara ilgi her geçen gün artmaktadır.

\section{Genetiği Değiştirilmiş Bitkiler}

Tarımsal ve ekonomik getirisi bakımından önem arz eden önemli bitkilerin yapısına, doğal yapısında olmayan genlerin başarılı olarak aktarılıp ifade edilebilmesi modern tarımda birçok uygulama alanı bulmuştur (Öztürk 2011). İlk transgenik bitkilerin üretiminin elde edildiği 1980'li yıllardan bu yana, transgenik bitkilerin kullanımı bitki biyoteknolojisinde tarımsal ilerlemeleri teşvik edici birçok yeni alanlar açmıştır (Sağıroğlu 1999; Kaynar 2009). Bu bitkilerin üretimine başlandığı dönemden günümüze kadar birçok transgenik zirai bitki geniş alanlarda ekilmeye başlanmış ve bunların ürünleri (un, yem vs.) çoktan marketlere kadar ulaşmıştır. Zamanla ülkeler arasında biyogüvenlik kanunları çerçevesinde genetiği değiştirilmiş ürünlerin ekilmesi ve/veya tüketilmesi konusunda farklılıklar oluşmaya başlamıştır. Ülkemizde, 2010 yılında yürürlüğe giren "biyogüvenlik kanunu” gereğince transgenik ürünlerin "hayvan yemi ve ek gida maddesi olarak tüketilmesi (bebek mamaları hariç) serbest bırakılmış fakat ekilmesi ve insan gıdası olarak kullanılması yasaklanmıştır (Biyogüvenlik Kanunu 2010).

Ticari amaçlı transgenik bitkilerin üretildiği alanlar temel olarak üç nesil sınıf altında toplanmaktadır. birincil, ikincil ve üçüncül nesil GDO (Smith 1996; Briggs ve Koziel 1998; Holmberg ve Bülow 1998; Ölçer 2001).

GD ürünlerin ticarileşmesinin ilk yıllarındaki çalışmalar herbisit toleransı, böcek ve patojen direnci gibi girdiye yönelik yani doğrudan çiftçiyi ilgilendiren, biyotik ve abiyotik stres faktörlerine dayanıklı tarım bitkilerinin yetiştirilmesine yardımcı olan özelliklere odaklanmış ve birinci nesil GDO olarak tanımlanmıştır (Öktem 2004a; Öktem 2004b; Yüzbaşığlu ve ark. 2017). Üretim aşamasında olan birinci nesil GDO'ların üretim amacı çiftçinin kâr oranını ve ürün verimini artırmak olmuştur (Korth 2008). Yaygın olarak kazandırılan herbisit toleransı özelliği, çiftçilerin ürün maliyetlerini önemli ölçüde azaltmaktadır. Ayrıca, özellikle mısır ve pamuk yetiştiriciliğinin yapıldığı alanlarda ürün verimine etki eden zararlı tırtıllara karşı etkili olan Bacillus thuringenis (Bt) den alınan cry geninin aktarıldığı bitkilerin üretimi sırasında pestisit kullanımı azalmaktadır. Ekonomik şartlar sağlayan bu uygulama uygulanan kimyasal ilaçların çevre ve insan sağlığına olumsuz etkilerini ortadan kaldıracaktır (Rahman ve ark. 2015; James 2016).

Tüketicilerin kullanımına yönelik geliştirilmiş bitkisel ürünler olan ikinci nesil GDO'lar geliştirme aşamasında olduğundan piyasada henüz çok yaygıı değildir (Meriç 2012). Biyoteknoloji yöntemleri aracılığıyla bitkilerin besin değerlerini değiştirmek veya geliştirmek amacıyla yapılan çalışmalar devam etmektedir. "Altın pirinç" adı verilen, içerdiği beta karoten/ A vitamini arttırılmış çeltik ikinci nesil GDO’lara verilebilecek en güncel örnektir (Ricroch ve ark. 2018).

Üçüncü Nesil GDO’lu ürünler ise yeşil fabrikalar olarak da tanımlanabilir. Bu GD nesil ürünlerde başlıca iki önemli özellik öne çıkmaktadır. Birincisi; insan sağlığı açısından çokça önem arz eden çok pahalı ilaç ve aşıları barındıran genlerin bitkilere aktarılmasını sağlayarak bitkilere ilaç özelliği kazandırmaktır. İkincisi ise ketencik (Camelina sativa L.), mısır, sorgum, kanola, soya ve ayçiçeği gibi yağlı tohumlu enerji bitkilerine gen aktarılarak biyoyakıt üretimi için yatkın bitkiler elde edilmesi çalışmalarıdır. Günümüzde halen AR-GE çalışmaları devam eden üçüncü nesil GDO'ların ilerleyen zamanlarda başarılı sonuçlar alınıp üretim aşamasına geçeceği düşünülmektedir (Nofouzi 2013). 
Günümüzde kronik karaciğer hastalığına neden olan Hepatit-B virüsü için mayalardan aşı geliştirilebilmiştir fakat aşının çok pahalı olması kullanımını sınırlandırmıştır. ABD’de biyoteknolojik yöntemler kullanılarak Hepatit-B yüzey antijeni üretimi yapan GD patates ve tütün bitkileri elde edilmiştir. Hepatit-B geni patateste başarılı şekilde ifade edilmiştir daha sonra bu geni barındıran patates yumruları farelere yedirilmiş ve deneyin sonunda farelerin savunma sistemlerinin istenilen şekilde tepki gösterdikleri görülmüştür (Korkut ve Soysal 2013). Muz bitkisi üzerinde de benzer çalışmalar Hindistan gibi gelişmekte olan ülkelerde yapılmaktadır (Kumar ve ark. 2005; Nofouzi 2013).

İlk GD ürün piyasaya çıktıktan sonra, küresel ölçekte yeni ve hızlı büyüyen bir sektör oluşmaya başlamıştır. Genetiği değiştirilmiş tohumların ekildiği tarım arazileri ise düzenli olarak artış göstermiştir (Yardımcı 2016). 2017 yılına kadar GD ürünlerin üretimi yaklaşık 110 kat artış göstererek toplam üretim alanı 189,8 milyon hektara çıkmıştır. Bundan dolayı transgenik ürünler son yıllarda tarım alanlarına en hızlı adaptasyon sağlayan teknolojik ürünler olmuşlardır. 2017 yılında transgenik ürün ekimi yapan 24 ülkenin 21'ni gelişmekte olan, kalan 3'ünü ise gelişmiş ülkelerin oluşturmakta olduğu belirtilmektedir (ISAAA 2017). 2017 yılı itibariyle yeryüzünde miktar olarak en çok genetiği değiştirilmiş bitkisel ürünler çoktan aza doğru pamuk, soya, mısır ve konola gibi ekonomik değere sahip ürünlerdir. 2017 yılı verilerine göre yeryüzünde üretilen 100 soyanın 77'si, 100 pamuktan 80'i, 100 mısırdan 22'si biyoteknolojik üründür (Şekil 2) (ISAAA 2017).

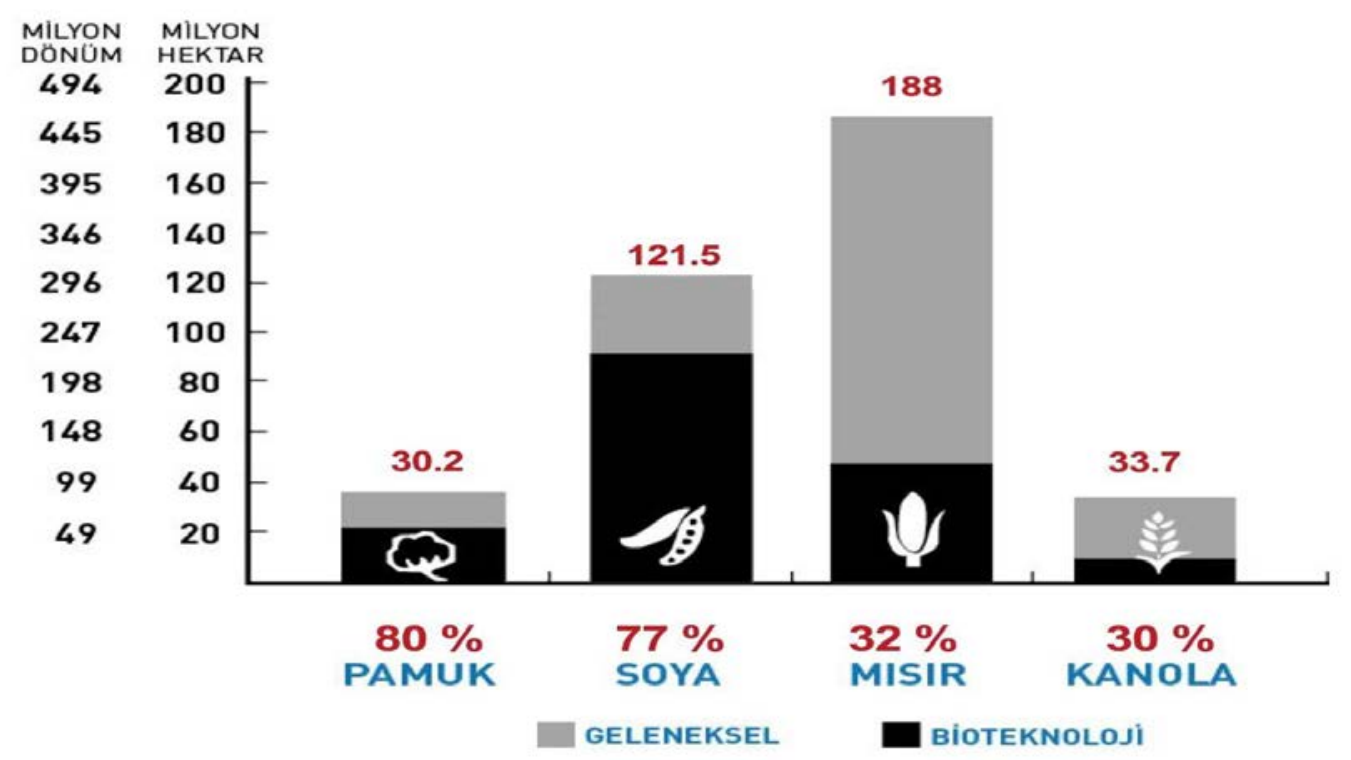

Şekil 2. En fazla üretilen transgenik ürünlerin küresel üretim miktarları (ISAAA 2017).

Bunlara ilaveten çeltik, balkabağ1, ayçiçeği, yer fıstığı gibi bitkisel ürünlerinde transgenik çeşitlerinin mevcut olduğu belirtilmektedir (ISAAA 2017). Transgenik ürünlerinin ithalatını yapan 43 olmak üzere toplam 67 ülke yasal düzenlemelere bağlı olarak transgenik ürünlerin üretimini ve/veya ithalatını kabul etmiştir (ISAAA 2017).

\section{Biyoçeşitlilik}

Biyoçeşitlilik, dünya üzerindeki tüm bitki ve hayvanlar ile hayvan ve bitki yaşamlarını destekleyen hava, su ve toprağın toplamı olarak tanımlanmaktadır. Biyoçeşitlilik spesifik olarak, doğal olarak oluşmuş veya insanlar tarafından genetiği değiştirilmiş canlı organizmalar, canlı organizmaların habitatlarını, biyotik toplulukları ve biyotik süreçler içindeki çeşitliliği belirtmektedir (Singh ve ark. 2017). Edward Wilson tarafından oluşturulan "Biyoçeşitlilik" terimi; canlıların sayısı, çeşitliliği ve tür içindeki değişkenlik anlamına gelmektedir. Biyoçeşitlilik, bir türün bireyleri arasındaki gen farklılıklarını kapsamaktadır. Karada ve suda yaşayan bütün bitki ve hayvan türlerinin çeşitliliği ve zenginliğini ifade etmektedir. Bu canlıların birbirleri ile olan akrabalık bağlarını belirli bir alanda, yerel olarak, bir bölgede, ülkede ve dünyadaki farklı alanlardaki çeşitli ekosistem türlerini içeren bir bütündür (Singh ve ark. 2017).

Biyoçeşitlilik; genetik çeşitlilik, biyotik topluluklar, farklı türde türlerin kimliği ve sayısı, türlerin toplulukları ve biyotik süreçleri ve her birinin miktarı (kişi sayısı, biyokütle, kapladığı alan, ekosistemdeki yeri ya da oranı) ve yapısı açısından ölçülebilir (Heywood ve Watson 1995). Genetik çeşitlilik bütün bitkiler, hayvanlar ve mikroorganizmaların tür popülasyonları içerisinde üyelerinin hepsinin ayrı ayrı sahip oldukları genetik bilginin çeşitliliği olarak ifade edilmektedir. Basit bir ifadeyle, türlerin ve popülasyonların içindeki genlerin çeşitlilik derecesini ifade etmektedir (Kaya ve Gökdoğan 2017). 
Biyoçeşitlilik, farklı büyüklüklerdeki birimler (tür, popülasyon, biyosenöz, habitat, çevre), farklı kompozisyonlar (genom, tür, popülasyon, ekosistem ve çevre elementlerinin bütünü) ve fonksiyonlar (hiyerarşik sistemin farklı seviyelerinde gerçekleşen olaylar) ile ilgili olarak bir aşama sırası göstermektedir (Noss 1990).

Biyoçeşitliliğin önemli bir parçasını bitki çeşitliliği oluşturmakta ve bitkiler insanoğlunun yaşamında önemli bir rol oynamaktadır (Dülger ve ark. 1997). Ancak, son yıllarda bitki çeşitliliği ciddi anlamda tehlike altındadır ve dünyadaki tüm bitki türlerinin 1/3'i olan yaklaşık 100.000 tür kaybolma riski taşımaktadır (Tan 1996). Oysaki hem beslenme hem de tedavi amaçlı kullanılan bitkilerin korunması ve gelecek nesillere devamlılığın sağlanması büyük için önem arz etmektedir (Benson 1999).

\section{Genetiği Değiştirilmiş Bitkilerin Biyolojik Çeşitliliğe Etkileri}

Rekombinant DNA teknolojileri gibi yeni bir teknolojinin riskleri ve faydaları düşünüldüğünde mevcut alternatifler ve eski teknolojilerle karşılaştırılmalıdır. Genetiği değiştirilmiş bitkilerin biyoçeşitliliğe etkilerini değerlendirmek için öncelikle tarıma şu an uygulandığı haliyle, özellikle de gelişmiş ve gelişmekte olan ülkelerdeki çevre üzerindeki etkilerine bakmak gereklidir. Bir GD ürününün ekolojik (veya sağlık) etkileri, bu ürünlerin yerini alacağı tarımsal uygulamaların etkilerine karşı dengelenmelidir. GD ürünlerinin çevreye olası riskleri çoğu zaman bölgeden bölgeye benzer etkilere sahiptir ancak otoriteler tarafindan bu risklerin değerlendirilmesi önemli ölçüde farklılık göstermektedir (Demirhan 2018).

Genetiği değiştirilmiş bitkilerin doğada mevcut bakteri, bitki ve hayvan genetik çeşitliliğinin azalmasına neden olacağı olgusu önemli bir kaygı olarak durmaktadır. Bunun anlamı, bir organizmadaki proteinleri kodlayan DNA'nın bir türün bireyleri arasında daha fazla benzerleşeceğidir ve neredeyse birbirlerinin klonları seviyesine geleceğidir (Çelik ve Balık 2007). Genetik çeşitlilik doğrudan biyoçeşitlilik ile ilgilidir, yani bir ekosistemi oluşturan canlıların özelliklerinde değişkenlik ile ilgilidir, çünkü DNA'daki çeşitlilik bir popülasyonu oluşturan canlıların özelliklerini ifade eder. Genetik çeşitliliğin korunması insan, ziraat ve doğa için önemlidir; çünkü DNA'daki artan değişkenlik, organizmaların doğada değişen şartlara uyum sağlamaları için daha iyi bir fırsat sağlamaktadır. Genetik çeşitliliğin eksikliğinin çok büyük bir tarım sorununa yol açacağının en yaygın bilinen örneği; İrlanda'da 1800'lü yılların ortalarında, yaklaşık bir buçuk milyon insanın ölümüne yol açan patates kıtlığıdır. O tarihte İrlanda'da, ağırlıklı olarak gıda tüketiminde patates kullanılmakta ve tek çeşit patates yumrusundan ürün elde edilmekteydi. Dolayısıyla uzun bir müddet tek çeşit patates ekimi gerçekleştirildiği için tek tohum genotipi bulunmaktaydı. Bu şekilde, tüm patatesler neredeyse ebeveynlerinin klonlarıydı ve aynı genetik bilgiyi içeriyordu. İlanda'da ekimi yapılan patates türlerinde genetik çeşitlilik eksikliği, istilacı bir patojen olan Phytophthora infestans, tüm popülasyonu yok ettiğinde zararlı olduğunu ortaya koymuştur (Gibbons 2013). İrlanda, birden çok genetik çeşitlilik gösteren farklı patates çeşitleri yetiştirmiş olsaydı, patojene dirençli patates çeşitleri üretimi mümkün kılardı. İrlanda'daki patates bitkilerinin büyük bir yüzdesi $P$. infestans'a karşı dirençli olsaydı, bu açlık bir felakete dönüşmeyebilirdi (Landry 2015). Genetik çeşitliliğin azalması bakımından, GD bitkilerin biyoçeşitliliği nasıl etkilediğine bakacak olursak: GD canlılar ile yabani ırklarının melezlenmesi ile ortaya istem dışı genetiği değiştirilmiş canlıların ortaya çıkması muhtemeldir. Buna ek olarak, GD bitkilerin mensup olduğu cinsin tamamını genetiksel bakımdan ele geçirmesine izin verebilir.

GDO’ların çevreye salınımları halinde doğurabileceği olumsuz sonuçlar çoğunlukla kontrolsüz tozlaşma, gen kaçışı ve yabani hibritleşmeden dolayı ortaya çıkan riskler olarak ifade edilmektedir (Şekil 4). Herhangi bir özellikle ilgili olarak aktarılan "yabancı genin” diğer türlere geçme olasılığını doğurabilir (Özdemir 2007). Böyle bir durumun meydana gelmesi halinde; insan ve hayvan sağlığı başta olmak üzere biyolojik çeşitlilik ve bütün ekosistem büyük bir sorun ile karşılaşacaktır (Yılmaz 2014).

Genetiği değiştirilmiş bir bitkinin kullanımı konusundaki genel endişelerden biri Bt mısır örneğinde olduğu gibi hedef olmayan canlıların zarar görmesidir. Bt mısır, mısır bitkisine Bacillus thuringiensis bakterisinden cry proteini kodlayan genleri genomu içerisinde barındıran mısır bitkisini ifade etmektedir. Bu bakteri çevre dostu biyolojik ajan olarak insektisitlerin yerine senelerce kullanılmıştır. Mısır bitkileri tarafından bu proteinin ekspresyonunun yararı, çiftçilerin ürünlerine uygulamak zorunda oldukları insektisit miktarında yüzde yüze yakın bir azalma sağlamasıdır. Fakat ne yazık ki, rekombinant protein geni içeren bt mısırlar, beklenmedik şekilde bazı faydalı böcekler ve arılar gibi hedef olmayan organizmaların ortamdaki yeni toksik bileşiklere maruz kalmasına neden olabilmektedir (Żmijewska ve ark. 2013). Yapılan çalışmalarda genetiği değiştirilmiş bitkilerin üretiminde kimyasal ilaç kullanımının artmasından dolayı toprak ve su kaynaklarında kirlenmenin arttığı ileri sürülmektedir. 1999 yılında Arjantin'de yabani çeşit soya fasulyesi ekilen alanlarda yaklaşık \%17'lik bir artış gerçekleşmiş bununla beraber kullanılan pestisit (tarım ilacı) miktarının da iki kat arttığı, aynı dönemde veriminde bir miktar düştüğü görülmüştür (Olhan 2010). Dolayısıyla kullanılan pestisit miktarının artması soya fasulyesi ekim alanındaki artışla ifade edilememiştir.

Dalapon herbisitine dirençli genetiği değiştirilmiş tütünlerin ekilmesi ile daha fazla herbisit kullanımı söz konusu olmuştur. Çünkü GD tütün doğal halinden en az 10 kat daha fazla herbisitlere dirençli olmuştur. Kullanılan bu herbisitler ise toprak ve suya daha fazla karışarak kalıcı kirlenmelere sebep olmuştur Yüksek dozda herbisit 
kullanılmasının nedeni ise zamanla herbisitlere direnç kazanan yabancı otlarla etkili bir şekilde mücadele edilebilmesidir (Kaya ve ark. 2013). Bununla beraber herbisitlerin daha fazla kullanılması topraklarda birikmeye sebep olmakta ve kirlenmelere neden olmaktadır. Ayrıca herbisitler ürünün içerisinde birikmekte ve kanser başta olmak üzere çeşitli ölümcül hastalıklara neden olmaktadır (Kaya ve Arvas 2017). Amerika'nın İndiana eyaletinde yaşayan farklı yaşlarda 71 hamile kadın üzerinde yürütülen bir araştırmada dünya çapında en çok kullanılan herbisit olan glifosatın (N-fosfonometilglisin) çevresel ve tüketilen gıdalarda birikmesi sonucu kadınların daha kısa gebelik dönemi geçirmelerine neden olduğu belirtilmiştir (Parvez ve ark. 2018). Bilindiği gibi gebelik süresinin (9 ay 10 gün) normal süreden şaşması doğum riskine neden olmaktadır. Herbisitlerin gıdalar aracılığıyla vücuda girmesi sonucunda ciddi sağlık riskleri oluşmaktadır. Transgenik ürünlerin yukarıda ifade edildiği gibi olumsuz neticelerinin görülmesi uluslararası kamu otoritelerinin yasal çalışmalar yaparak, gıda arz güvenliği ve biyolojik çeşitliliğin koruma altına alınmasını sağlamıştır. Bu bağlamda yapılan çalışmalardan birisi 1992 yılında gerçekleştirilen Dünya Sürdürülebilir Kalkınma Zirvesi’nde kabul edilen ve 1993’te yürürlüğe giren BM Biyolojik Çeşitlilik Sözleşmesidir. Bu sözleşme ekonomik ve sosyal kalkınma açısından çok önem arz eden biyolojik çeşitliliğin insan kaynaklı faaliyetlerden dolayı zarar görmesi ve bazı türlerin soyunun tükenmesinin endişe verici oranlara ulaşması nedeniyle imzalanmıştır. Böylece ülkelerin biyoçeşitlilikleri koruma altına alınmıştır. Türkiye'nin 1996 yılında taraf olduğu bu sözleşme'ye hâlihazırda AB ülkeleri dâhil 195 ülke taraftır. Bu sözleşme, biyolojik çeşitliliğin korunması ve sürdürülebilirlik ilkeleri bağlamında ulusal stratejilerin belirlenmesini, eylem planları ve programların geliştirilmesini öngörmektedir. Bilindiği üzere Türkiye 3 farklı iklim kuşağı ve 3 biyocoğrafi alan üzerinde yer alan ve biyolojik çeşitlilik bakımından zengin bir ülke konumundadır. Bu anlamda özellikle biyolojik çeşitliliğin korunması Türkiye için çok önem arz etmektedir. Modern biyoteknoloji kullanılarak transgenik organizma elde etme çalışmaları için BM Biyolojik Çeşitlilik Sözleşmesi’ne ek olarak 2003 yılında Cartagena Biyogüvenlik Protokolü yürürlüğe girmiştir. Bu protokolün imzalanmasının nedeni; genetiği değiştirilmiş organizmaların biyolojik çeşitliliğinin korunması ve sürdürülebilir kullanımı üzerinde olumsuz etkilere neden olabileceğidir. Protokol kapsamında; transgenik ürünlerin; nakli, üretimi, taşınması ve kullanılması için yeterli koruma düzeyinin sağlanmasına katkıda bulunmak amacını kapsayan maddeler bulunmaktadır. Türkiye, protokole, 2004 yılında taraf olmuştur (BM Biyolojik Çeşitlilik Sözleşmesi 2011).

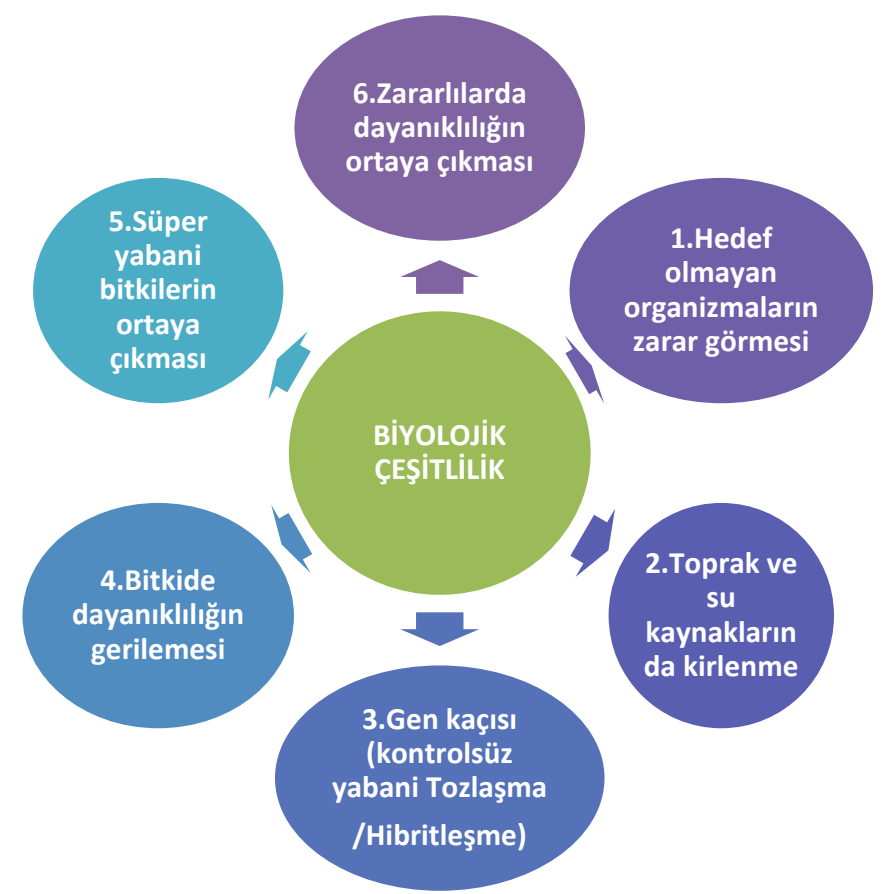

Şekil 4. GDO’ların biyoçeşitlilik üzerine etkileri (Arvas 2017).

Genetiği değiştirilmiş organizmalarla ilgili endişe verici diğer bir durum ise bitkilerde dayanıklılığın gerilemesi ve/veya zararlılarda dayanıklılığın ortaya çıkmasıdır. Yukarıda ifade edildiği gibi GD bitkilerden yabani ve/veya kültür bitkilerinin genomuna rekombinant genetik materyaller transfer edilebilmektedir. Hastalığa dirençli genetiği değiştirilmiş bitkiler tarafından eşlik edilen potansiyel riskler bitkinin dayanaklığının gerilemesidir ve bu durum çoğunlukla virüs direnci ile ilgilidir. Virüs direncinin yeni virüslerin oluşumuna ve dolayısıyla yeni hastalıklara yol açması olasıdır. Doğal olarak oluşan virüslerin, yeni virüsler oluşturarak transgenik bitkiler oluşturmak için vektör olarak kullanılabileceği bildirilmiştir. Ayrıca, bu yeni oluşan virüsün birçok varyasyonu olabileceği için olası bir istenmeyen durum ile karşılaşıldığında hızlı bir şekilde önlem alınması halen mümkün değildir. Böyle bir durumun gerçekleşmesi neticesinde yüzde yüze yakın ürün kaybı oluşması söz konusudur.

Genetiği değiştirilmiş organizmalarla ilgili en endişe verici diğer bir durum ise, herbisite dayanıklı bitkilerin "süper yabani bitkileri" ortaya çıkarıp çıkarmayacağı belirsizliğidir. Çünkü pestisitlerin normal kullanılacak miktardan çok 
daha fazla kullanılması, doğada pestisitlere dirençli dayanıklı istenmeyen bitkilerin ortaya çıkmasına neden olabilecektir. Örnek olarak GD soya fasulyesi ekilen alanlarda süper yabani bitkiler görülmeye başlanmıştır (Swaminathan 2015). Son yıllarda yürütülen çalışmalar ile GDO'ların çevreye salınımı ve kullanımı sonucunda, doğada birçok olumsuz etkiler doğurduğuna yönelik sonuçlar ortaya konulmaktadır. Genetiği değiştirilmiş bitkilerin yukarıda ifade edildiği gibi birçok yan etkisi ve zararları mevcuttur. Buna rağmen biyoçeşitlilik bakımından bazı olumlu etkileri de bilim insanları tarafından kaydedilmiştir. Mesela, yapılan araştırmalar neticesinde GD ürün ekiminin yapıldığı arazi kullanım değişikliğini hızlandırabileceğini göstermektedir. Arjantin'inin kuzeybatısındaki bazı mevsimler, kurak geçen ormanlarda ormansızlaşma üzerine yapılan bir çalışmada; ilk ormansızlaşmanın 1970'lerde siyah fasülye tarımı ve 1980'lerde yüksek soya fasulyesiyle ilişkili olduğu sonucuna varılmıştır (Grau ve ark., 2005). GD ekinlerinden birim alandan daha fazla verim elde edilmesi amaçlandığ için mevcut ekilen arazilerin verimi arttırılarak daha fazla ormansızlaşmanın önüne geçilmektedir (Anonim 2007).

Genetiği değiştirilmiş organizmaların biyoçeşitliliğe sunduğu katkıların bir diğer boyutu ise, pestisit kullanımında azalma, toprak ve suyun korunması, kirli toprakların temizlenmesi gibi doğrudan çevreyi ve canlıları etkileyen unsurların sağlıklı bir şekilde kullanılmasını sağlamasıdır. Bilindiği üzere herbisitler, zirai ilaçlar ve gübrelerin uygulanmasına yönelik modern tarım uygulamaları, dünyanın birçok yerinde ağır çevresel hasarlara neden olmuştur (Anonim 2005; Anonim 2017). Rekombinant DNA teknolojisi kullanılarak bitkilere aktarılan genler sayesinde dünya çapında büyük bir ürün kaybına yol açan ve geleneksel tarıma kıyasla herbisit ve böcek direncini büyük miktarda azalttığı görülmüştür. Örneğin, GD ürünlerinin piyasaya sürüldüğü ilk on y1lda, bu ürünleri yetiştiren çiftçiler geleneksel bitkilerin yetiştiriciliğinde kullandıklarından 172.500 ton daha az pestisit kullanmışlardır (Coghlan 2006). 2017 yılı verilerine göre herbisite dirençli transgenik ürünler, 88.7 milyon hektarlık ekim alanı ile GD bitkiler arasında \% 47’lik bir pay ile ilk sırada gelmektedir (ISAAA 2017). Bunların yanı sıra biyotik ve/veya abiyotik streslerden dolayı soyu tükenmek üzere olan bitkiler rekombinant DNA teknolojileri sayesinde çoğaltılabilir ve klonlanarak üretilebilinir. Bunlara ilave olarak kimyasallarla kirletilmiş ve doğal yollarla temizlenmesi mümkün olmayan ya da çok uzun sürede temizlenebilme kapasitesi olan topraklar genetiği değiştirilmiş bitkiler sayesinde fitoremidasyon yöntemi gibi biyoremidasyon metotlarıyla temizlenebilir ve kısa sürede doğaya tekrar kazandırılabilir.

\section{Sonuç}

Genetiği değiştirilmiş bitki ilk transgenik ürünün piyasaya sürüldüğü 1994 yılından itibaren birçok ülkede marketlerde satılmaya başlanmış ve hızlı bir surette yaygınlaşmıştır. Her geçen gün kullanımı artan bu yeni transgenik çeşitlerin insan sağlığı, çevre ve biyoçeşitlilik üzerinde görülen bazı olumsuz durumlarından dolayı kamuoyunda bazı endişeler oluşmuştur. Bitkilere kazandırılan bu yeni özelliklerin bitkinin yaşadığı çevrenin ve florasının bozulmasına, bazı doğal türlerin genetik çeşitliliğinin zamanla kaybolmasına, ekosistemdeki tür dağılımının ve dengesinin bozulup bazı yabani türlerin yok olmasına neden olacağı düşünülmektedir. Bu endişelerin ve biyoçeşitlilik risklerinin önlenmesi için genetiği değiştirilmiş bitkilere alternatif olarak yeni metotlar ve biyoteknolojik yöntemler kullanılarak yeni çeşitler geliştirilmelidir. Örneğin, hâlihazırda ekimi yapılan bitkisel ürünlerin verimini arttırmak için yabani genotiplerinin geleneksel ıslah yöntemleri ve/veya rekombinant DNA teknolojileri kullanılarak besin içerikleri yüksek yeni çeşitlerin elde edilmesi sağlanabilir veya zararlılara gen düzeyinde müdahale edilerek oluşan bitkisel ürün kaybının önüne geçilebilir. Aksoy ve arkadaşları tarafından 2017 yılında yapılan bir çalışmada Erwinia amylovora zararlısına gen düzeyinde müdahale edilerek zarar oluşturmalarının önüne geçildiği ifade edilmiştir (Aksoy ve ark. 2017a; Aksoy ve ark. 2017b). Yine Aksoy ve arkadaşlarının başka bir çalışmasında ise, bazı faydalı bakterilerin biyolojik mücadele ajanı olarak kullanılmasıyla domateslerde zararlılara karşı mücadelede olumlu sonuçlar alındığı ifade edilmiştir (Aksoy ve ark. 2017c). Bu perspektifle, transgenik bitki elde edilirken ileriye yönelik biyolojik çeşitliliğin ve doğal alanların korunabilmesi için gerekli hukuki, etik ve yasal önlemlerin alınması son derece önem arz etmektedir. Türkiye biyoçeşitlilik açısından çok zengin olduğundan dolayı özellikle tarımsal üretimde genetiği değiştirilmiş ürünlerin kapsamlı olarak ele alınması gerekmektedir. Aslında 2010 yılında yürürlüğe giren "biyogüvenlik kanunu” gereğince ülkemizde transgenik ürünlerin araştırma, geliştirme, işleme, piyasaya sürme, izleme, kullanma, ithalat ve ihracatı yasaklanmıştır. Fakat özellikle bazı hayvansal yemler için gerekli izinler alınarak ülkemize girişine izin verilen transgenik ürünler bulunmaktadır. Üzerinde durulması gereken diğer bir husus ise yurtdışından ithal ettiğimiz her bir zirai ürünün genetiğinin değiştirilmiş olması gün geçtikçe artan bir ihtimal olmaktadır. Bundan dolayı gereken her türlü yasal düzenlemelerin geciktirilmeden ve biyoçeşitiliğin korunması temel alınacak şekilde bütüncül bir anlayış benimsenmelidir. Türkiye'nin coğrafik yapısı ile bitkisel gen kaynaklarının özel şartlar da dâhil olmak üzere korunarak, Avrupa birliğinin bu konudaki kuralları da göz önüne alınıp, uluslararası sözleşmelerden kaynaklanan yükümlülüklerin uygulanması önem arz etmektedir. Özellikle endemik tür sayısı bakımından ülkemizin sahip olduğu zenginliğin farkına varılarak genetiği değiştirilmiş bitkilerin olumsuz etkilerini en aza indirmek için kapsamlı önlemler alınmalıdır. 


\section{Kaynaklar}

Aksoy H M, Kaya Y, Hamid T (2017a). The Role Of Dspf, The Type Iii Secretion Chaperone of Dspa/E Of Erwinia Amylovora, In Pathogenicity In Host And Non-Host Plants. JAPS: Journal of Animal \& Plant Sciences, 27(1).

Aksoy H M, Kaya Y, Ozturk M, Secgin Z, Onder H, Okumus A (2017b). Pseudomonas putida-Induced response in phenolic profile of tomato seedlings (Solanum lycopersicum L.) infected by Clavibacter michiganensis subsp. michiganensis. Biological Control, 105: 6-12.

Aksoy H M, Kaya Y, Tengku Abdul Hamid T H (2017c). Expression of the dspA/E gene of Erwinia amylovora in non-host plant Arabidopsis thaliana. Biotechnology \& Biotechnological Equipment, 31(1): 85-90.

Anonim (2005). MA (Millennium Ecosystem Assessment). Retrieved from Kuala Lumpur, Malaysia:http://www.millenniumassessment.org/en/Products.Synthesis.aspx [Erişim Tarihi: 22.08.2017].

Anonim (2007). (IUCN) The World Conservation Union. Current Knowledge Of The Impacts Of Genetically Modified Organisms On Biodiversity And Human Health. Impacts of GMOs on biodiversity and human health - Information Paper. Retrieved from https://cmsdata.iucn.org/downloads/ip_gmo_09_2007_1_.pdf

Anonim (2017). Third World Academy of Sciences. Transgenic plants and human health and safety. Retrieved from http://stills.nap.edu/html/transgenic/safety.html [Erişim Tarihi 22.08.2017].

Arun Ö Ö, Muratoğlu K, Eker F Y (2015). Genetiği Değiştirilmiş Organizmalar Kavramına Genel Bakış. İstanbul Üniversitesi Veteriner Fakültesi Dergisi, 41(1): 113-123.

Arvas Y E (2017). Genetiği Değiştirilmiş Bitkiler ve Tanısı. Lambert Yayınevi, Düsseldorf, Germany.

Atsan T, Kaya T E (2008). Genetiği değiştirilmiş organizmaların (GDO) tarım ve insan sağlığı üzerine etkileri. Uludağ Üniversitesi Ziraat Fakültesi Dergisi, 22(2).

Bawa A, Anilakumar K (2013). Genetically modified foods: safety, risks and public concerns_a review. Journal of food science and technology, 50(6): 1035-1046.

Benson E E (1999). An introduction to plant conservation biotechnology. Plant conservation biotechnology: 3-10.

Biyogüvenlik Kanunu. Türkiye Cumhuriyeti Resmi Gazete. Biyogüvenlik Kanunu: Kanun numarası 5977. Resmi Gazete, 27533/Tarih: 26.03.2010.

Biyolojik Çeşitlilik Sözleşmesi (2011). Temel Dış Politika Konuları, Türkiye'nin Çevre Politikası, Uluslararası Süreçler ve Türkiye. Dışişleri Bakanlığg. Retrieved from http://www.mfa.gov.tr/biyolojik-cesitlilik.tr.mfa [Erişim Tarihi: 10.07.2018].

Briggs S P, Koziel M (1998). Engineering new plant strains for commercial markets. Current opinion in biotechnology, 9(2): 233-235.

Coghlan A (2006). Genetically modified crops: a decade of disagreement. New Scientist, 2535: 21

Çelik V, Balık D T (2007). Genetiği değiştirilmiş organizmalar (GDO). Erciyes Üniversitesi Fen Bilimleri Enstitüsü Dergisi. 23 (1-2) $13-23$.

Demirhan B (2018). Patates ve İşlenmiş Patates Ürünlerinde Genetiği Değiştirilmiş Organizmalarla ilgili Genetik Analizler. Yüksek Lisans Tezi. Ondokuz Mayıs Üniversitesi Tarımsal Biyoreknoloji, Samsun, Türkiye.

Dülger B, Gücin F, Malyer H, Bicakci A (1997). Antimicrobial activity of Marigold (Tagetes Minuta L.). Acta Pharmaceutica Turcica, 39: 115-118.

Firidin Ş (2010). Rekombinant DNA Teknolojisi. Yunus Araştırma Bülteni: (10):16-18.

Gibbons A (2013). Potato Famine Pathogen’s DNA Sequenced, Solving Scienti. Retrieved from http://www.huffingtonpost.com/2013/05/23/potato-famine-pathogen-dna-sequencedmystery_n_3320547.html.

Gostin L O, Altevogt B M, Lenzi R N (2014). Oversight and review of clinical gene transfer protocols: assessing the role of the recombinant DNA advisory committee. National Academies Press.

Grau H R, Gasparri N I, Aide T M (2005). Agriculture expansion and deforestation in seasonally dry forests of northwest Argentina. Environmental Conservation, 32(2): 140-148.

Herrera-Estrella L, De Block M, Messens E, Hernalsteens J P, Van Montagu M, Schell J (1983). Chimeric genes as dominant selectable markers in plant cells. The EMBO journal, 2(6): 987-995.

Heywood V, Watson R (1995). Global Biodiversity Assessment Cambridge University Press Cambridge. UK Google Scholar

Hoffmann T (1997). Gentransfer bei höheren Pflanzen. Biologische Grundlagen der Pflanzenzüchtung. Parey Bucherverlag, Berlin: 275-323.

Holmberg N, Bülow L (1998). Improving stress tolerance in plants by gene transfer. Trends in plant science, 3(2): 6166.

ISAAA (2017). Global Status of Commercialized Biotech/GM Crops in 2017: Biotech Crop Adoption Surges as Economic Benefits Accumulate in 22 Years. . The International Service for the Acquisition of Agri-biotech Applications (ISAAA). Ithaca, NY.

James C (2016). Gobal status of commercialized biotech/GM crops. Retrieved from Retrieved from http://www.isaaa.org/default.asp [Erişim Tarihi: 22.08.2017]. 
Kaya E Y, Gökdoğan E (2017). Bitki Biyoçeşitliliğinin Kısa, Orta ve Uzun Süreli Korunması: Biyoteknoloji ve Kriyoprezervasyon. Mustafa Kemal Üniversitesi Ziraat Fakültesi Dergisi. 22(1):87-111.

Kaya Y (2015). Genetically modified plants and their biosecurity risks. Halal and Tayyip Products Fiqh, Medicine Pharmaceuticals, Cosmetics and Tourisms Workshop. Gimdes, İstanbul.

Kaya Y, Arvas Y E (2017). Doğal Hayat Alanlarımızdaki Doğal Olmayan Pestisit Kalıntılarına Genel Bir Bakış. (Gimdes) Helal Yaşam Rehberi, 52: p. 20-24.

Kaya Y, Marakli S, Gozikirmizi N, Mohamed E, Javed M, Huyop F (2013). Herbicide tolerance genes derived from bacteria. The Journal of Animal and Plant Sciences, 23(1): 85-91.

Kaynar P (2009). Genetik Olarak Değiştirilmiş Organizmalar (Gdo)’A Genel Bir Bakiş. Türk Hijyen ve Deneysel Biyoloji Dergisi: 177.

Kenward K D, Altschuler M, Hildebrand D, Davies P L (1993). Accumulation of type I fish antifreeze protein in transgenic tobacco is cold-specific. Plant molecular biology, 23(2): 377-385.

Kiermer V (2007). The dawn of recombinant DNA. Nature Milestones DNA Technologies

Korkut D, Soysal A (2013). Genetiği Değiştirilmiş Organizmalar. Ankara: Halk Sağlığı Uzmanları Derneği (HASUDER). Lönnerdal, B.(2003). Genetically Modified Plants for Improved Trace Element Nutrition.(133), 1430, 1433.

Korth K L (2008). Bitki Biyoteknolojisi ve Genetik (Nobel Akademik Yayıncılık, 193-216.

Krebs J E, Lewin B, Goldstein E S, Kilpatrick S T (2014). Lewin's genes XI. Jones \& Bartlett Publishers.

Landry H (2015). Challenging Evolution: How GMOs Can Influence Genetic Diversity. Retrieved from http://sitn.hms.harvard.edu/flash/2015/challenging-evolution-how-gmos-can-influence-genetic-diversity [Erişim Tarihi: 23.08.2017].

Lodish H, Berk A, Zipursky S, Matsudaira P, Baltimore D, Darnell J (2000). Collagen: the fibrous proteins of the matrix. Molecular Cell Biology, 176-190.

Melchers L S, Stuiver M H (2000). Novel genes for disease-resistance breeding. Current opinion in plant biology, $3(2): 147-152$

Meriç S (2012). Mısır İçeren Gıda Ve Yem Çeşitlerinde Genetiği Değiştirilmiş Organizmalarla ilgili Genetik Analizler. Yüksek Lisans Tezi. İstanbul Üniversitesi Moleküler Biyoloji ve Genetik Anabilim Dalı, İstanbul.

National Human Genome Research Institute (2015). Genetic Timeline. https://www.genome.gov/pages/education/genetictimeline.pdf

Nofouzi F (2013). Genetiği Değiştirilmiş Organizma (GDO) Nedir ve Nasıl Yapılmaktadır. Güncel Gastroenteroloji dergisi, 17(4): 1-7. Retrieved from http://www.guncel.tgv.org.tr/makale.php?mid=100137

Noss R F (1990). Indicators for monitoring biodiversity: a hierarchical approach. Conservation biology, 4(4): 355364.

Olhan E (2010). Modern Biyoteknolojinin tarımda kullanımının politik ve ekonomik yönden değerlendirilmesi. Ankara Tabip Odası Farklı Boyutlarıyla Genetiği Değiştirilmiş Organizmalar Kitabı: 9-14.

Öktem A (2004a). Herbisitlere Dayanıklı Transgenik Bitkilerin Yetiştirilmesi: Bitki Biyoteknolojisi II-Doku Kültürü ve Uygulamaları. Selçuk Üniversitesi Vakfı Yayınları, Konya: ss 238.

Öktem H (2004b). Böceklere Dayanıklı Transgenik Bitkilerin Geliştirilmesi. Bitki Biyoteknolojisi II, Genetik Mühendisliği ve Uygulamaları. Selçuk Üniversitesi Vakfı Yayınları, Konya: 208-238

Ölçer H (2001). Transgenik bitkiler: Tarımsal uygulamaları, üretim ve tüketiminin kontrolü. Ekoloji Çevre Dergisi, 40: $20-23$

Özdemir O (2007). Gen Kaynaklarının Sürdürülebilirliği Açısından GDO’ların Sosyoekonomik Etkileri. Ankara Biyoteknoloji Günleri: Biyoteknoloji, Biyogüvenlik ve Sosyo-Ekonomik Yaklaşımlar, Ankara Üniversitesi Biyoteknoloji Enstitüsü, Ankara.

Öztürk D (2011). Mısır Kökenli Gıdalarda Yabancı Gen Taranması. Yüksek Lisans Tezi. İstanbul Üniversitesi Moleküler Biyoloji ve Genetik Anabilim Dalı, İstanbul.

Parvez S, Gerona R, Proctor C, Friesen M, Ashby J, Reiter J, Winchester P (2018). Glyphosate exposure in pregnancy and shortened gestational length: a prospective Indiana birth cohort study. Environmental Health, 17(1): 23.

Pray L (2008). Recombinant DNA technology and transgenic animals. Nature Education, 1(1): 51.

Rahman M, Zaman M, Shaheen T, Irem S, Zafar Y (2015). Safe use of Cry genes in genetically modified crops. Environmental chemistry letters, 13(3): 239-24.

Ricroch A E, Guillaume-Hofnung M, Kuntz M (2018). The ethical concerns about transgenic crops. Biochemical Journal, 475 (4) 803-811; DOI: 10.1042/BCJ20170794.

Sağıroğlu A K (1999). Genetik Mühendisliği. Bilim ve Teknik, 34-41,

Singh P K, Chauan R S, Singh P (2017). Principles and Applications of Environmental Biotechnology for a Sustainable Future. Springer Link., 315-340.

Smith J E (1996). Biotechnology. Cambridge University Press, 149-158.

Soydemir E, Aksoy Z B (2017). Rekombinant DNA Teknolojisi ve Günümüzdeki Kullanımı. Güncel gastroenteroloji, 21/1:14-17. http://www.guncel.tgv.org.tr/makale.php?mid=100515.

Swaminathan M S (2015). The hidden use of Genetically Modified Organisms and their impact on Human Beings, Animals and Nature. The World Foundation for Natural Science, 1-6, 
Şen S, Altınkaynak S (2014). Genetiği değiştirilmiş gıdalar ve potansiyel sağlık riskleri. Sakarya Üniversitesi Fen Bilimleri Enstitüsü Dergisi, 18(1): 31-38

Tan A (1996). Turkey; Country report to the FAO international technical conference on plant genetic resource.

Yardımcı H (2016). "Biyogüvenlik mevzuatı ve gereksinimler" GDO-2016: Genom Teknolojilerindeki Gelişmeler ve Biyogüvenlik Mevzuatının Değerlendirilmesi Çalıştayı. (Vol. 1, pp. 5-5). İstanbul.

Yılmaz F (2014). Bitkisel Üretimde Genetiği Değiştirilmiş Organizmalar ve Ürünleri ile Biyogüvenlik. Uzmanlık Tezi, Ankara.

Yılmaz M M (2012). Türkiye'deki İşlenmiş Soya Ürünlerinde Kalitatif Ve Kantitatif GDO Tanısı ve Transgen Analizi. Yüksek Lisans Tezi. İstanbul Üniversitesi Moleküler Biyoloji ve Genetik Anabilim Dalı, İstanbul.

Yorulmaz S, Ay R (2006). Genetigi Degistirilmis Organizmaların (GDO) Entomoloji Alanındaki Uygulama Olanakları. Süleyman Demirel Üniversitesi Ziraat Fakültesi Dergisi, 1(2): 53-59.

Yüzbaşığlu G, Maraklı S, Gözükırmızı N (2017). Screening of Oryza sativa L. for Hpt Gene and Evaluation of Hpt Positive Samples Using Houba Retransposon-Based IRAP Markers. Retrieved from http://dergipark.gov.tr/download/article-file/287034.

Żmijewska E, Teper D, Linkiewicz A, Sowa S (2013). Pollen from genetically modified plants in honey-problems with quantification and proper labelling. Journal of Apicultural Science, 57(2): 5-19. 